\title{
ANALISIS KEBIJAKAN PEMERINTAH TENTANG PENCEGAHAN DAN PENANGANAN KORBAN PERDAGANGAN (TRAFFICKING) PEREMPUAN DAN ANAK DI KABUPATEN CIANJUR
}

\author{
Dian Fitriani Afifah \\ Neneng Yani Yuningsih \\ Departemen Ilmu Pemerintahan FISIP \\ Universitas Padjadjaran \\ e-mail: dianfitrianiafifah92@gmail.com
}

\begin{abstract}
ABSTRAK
Eksploitasi seksual dan tenaga kerja yang terjadi pada perempuan dan anak malalui perdagangan manusia merupakan kejahatan kemanusiaan yang melanggar Hak Asasi Manusia. Cianjur merupakan Kabupaten peringkat ke tiga untuk jumlah korban perdagangan manusia di Jawa Barat, dengan peningkatan jumlah korban setiap tahunnya. Analisis kebijakan pemerintah tentang pencegahan dan penanganan tindak pidana perdagangan (trafficking) perempuan dan anak di Kabupaten Cianjur pada tahun 20112013, menjadi judul dari penelitian ini. Melalui analisis kebijakan, penelitian ini akan mendeskripsikan dan menganalisis terkait nilai, fakta dan tindakan dari kebijakan pemerintah. Metode yang digunakan dalam penelitian ini adalah metode deskriptif dengan pendekatan kualitatif. Pengumpulan data yang dilakukan melalui studi pustaka dan studi lapangan berupa observasi, wawancara dan dokumentasi. Sedangkan informan ditentukan secara purposive. Hasil penelitian menunjukkan bahwa Kabupaten Cianjur telah mengeluarkan beberapa kebijakan namun faktanya hingga saat ini permasalahan perdagangan manusia belum terselesaikan dengan baik. Salah satu faktor penyebabnya adalah lemahnya koordinasi dan kerjasama antar sesama anggota Gugus Tugas. Sehingga dibutuhkan beberapa tindakan seperti peningkatan kualitas pejabat publik; adanya evaluasi, adanya punishment (hukuman); perbaikan dalam perumusan program; dan pemilihan media sosial. Langkah awal untuk merealisasikan ini semua adalah dengan penguatan kelembagaan P2TP2A.
\end{abstract}

Kata Kunci: Perdagangan Manusia, Kebijakan Pemerintah, Analisis Kebijakan.

\begin{abstract}
Sexual Exploitation and workers that happens to women and children through human trafficking is the part of human crime that breaks the Human Rights. Cianjur is the third rank regency of human trafficking victim in West Java, with the increase of the victim every year. The analysis of the government policy about prevention and handling of the women and children trafficking suspect in Cianjur Regency at 2011-2013, become the title of this research. Through the analysis of policy, this research would describe and analyze about values, facts, and acts from the government's policy. The method used in this research is the descriptive method with qualitative approachment. The accumulation of data that would be used through books study, and field study are observation, interview, and documentation. Meanwhile the informant is would be chosen purposively. The result of this research proves that Cianjur Region has already release some policy, but the fact, until at this time trafficking's problems yet to finish goodly. The causative factor is the weakness of teamwork and coordination between the members of the workgoups. So it takes some actions such as the quality enhancement of public officials,
\end{abstract}


hade some evaluations, improvements in the program formulation, and the election of sosial media. The fist step to objectify all of these is to strengthening the P2TP2A institutional.

Keywords: Human Trafficking, Government's Policy, Policy Analysis.

\section{PENDAHULUAN}

Perdagangan manusia (human trafficking) adalah salah satu kejahatan kemanusiaan, karena jelas permasalahan ini melangggar Hak Asasi Manusia. Adapun beberapa contoh hak asasi yang dilanggar diantaranya adalah, hak atas hidup (right to life); hak untuk tidak di siksa (no one shall be subjected to torture); hak atas kebebasan dan keamanan dirinya (right to liberty and security of person); hak atas kesamaan di muka badan-badan peradilan (right to equality before the court and tribunals);.......". (Budiarjo, 2000: 126)

Perdagangan manusia rentan terjadi pada perempuan dan anakanak. Anak adalah setiap orang yang berusia dibawah usia 18 , dimana ia belum cukup dewasa untuk membuat pilihan. Pentingnya perlindungan terhadap seorang anak, maka seorang bernama Eglantyne Jebb membuat rancangan Deklarasi Hak Anak (Declaration of The Right of Child), berisi 10 butir pernyataan tentang hak anak. Tahun 1924, Deklarasi Hak Anak tersebut diadopsi oleh Liga Bangsa-Bangsa (LBB). Setelah berakhirnya Perang Dunia II pada 10 Desember 1948, Majelis Umum PBB mengadopsi Deklarasi Universal Hak Asasi Manusia (DUHAM). Sebagai contoh, Pasal 25 ayat 2 DUHAM menyebutkan, “ ibu dan anak berhak memperoleh perawatan dan bantuan istimewa" (Rosana, 2007:15). Sedangkan Indonesia juga terlibat dalam hal ini dengan mengeluarkan Undang-Undang No. 23 Tahun 2002 tentang Perlindungan anak, UndangUndang No. 21 Tahun 2007 tentang Pemberantasan Tindak Pidana Perdagangan Orang, dan sebagainya.

Jumlah perempuan dan anak yang menjadi korban trafficking sudah tidak terhitung lagi. Selain kerena begitu banyak perempuan dan anak yang menjadi korban, juga tidak pernah ada data kongkrit untuk keseluruhan data trafficking di Indonesia. Menurut data yang dikeluarkan oleh International Organization for Migration (IOM), kasus perdagangan manusia atau human trafficking di Indonesia semakin mencengangkan. Data yang dirilis pada tahun 2011, Indonesia menempati peringkat teratas dengan jumlah 3.943 korban perdagangan manusia. Selain itu Setidaknya 90,3\% korban tindak pidana perdagangan orang adalah perempuan dan 23,6\% anak-anak, yang merupakan kelompok rentan terhadap kekerasan ${ }^{1}$.

\footnotetext{
1 Kanal 3. Kasus Perdagangan Manusia Indonesia Tertinggi di Dunia. 24 Januari 2014. http://kanaltiga.blogspot.com.
} 
Data di atas menunjukkan bahwa perempuan dan anak menempati angka trafficking yang lebih tinggi dari pada laki-laki. Karena disebagian daerah di Indonesia yang memiliki angka trafficking yang tinggi, posisi anak baik anak laki-laki maupun perempuan masih menjadi aset bagi keluarga, akan tetapi anak perempuan mendapatkan perlakuan "berbeda" karena sebagai harapan hidup bagi orang tua kedepannya.

Permasalahan Trafficking adalah isu laten yang mendapat perhatian dari semua pihak. Pemerintah harus serius dan bekerja keras agar angka perdagangan manusia dapat dihilangkan. Namun hal ini menimbulkan permasalahan baru ketika disatu sisi pemerintah serius untuk menangani permasalahan trafficking dengan membuat kebijakan-kebijakan pencegahan dan penanganan korban perdagangan manusia. Namun disisi lain pemerintah juga membuka keran pengiriman buruh migran ke luar negeri, dimana hal ini menjadi peluang atau salah satu faktor penyebab terjadinya trafficking atau perdagangan manusia.

Tercatat kurang lebih terdapat 10 Peraturan Perundang-Undangan yang dibuat dari tingkat nasional hingga daerah sebagai political will dari pemerintah untuk mencegah dan menangani permasalahan ini, namun faktanya adanya political will dari pemerintah belum membawa perubahan yang signifikan. Dalam berbagai studi dan laporan dari sejumlah LSM menyatakan bahwa Indonesia masih merupakan daerah sumber trafficking, disamping juga sebagai transit dan penerima perdagangan manusia. Sedikitnya diidentifikasi 10 provinsi di Indonesia yang dijadikan sebagai sumber, 16 provinsi dijadikan sebagai tempat transit, dan sedikitnya 12 provinsi sebagai penerima. Belum ditemukan jumlah yang akurat untuk jumlah perempuan dan anak korban trafficking di Indonesia. Data yang tersedia beragam dari 74.616 orang hingga 1 juta pertahun ${ }^{2}$.

Dalam Penelitian program desentralisasi, analisis kebijakan pemerintah tentang pencegahan dan penenganan korban perdagangan orang (trafficking) di Kabupaten Garut tahun 2013 oleh LPPM Unpad 2013, salah satu provinsi yang juga menjadi penyumbang terbesar dalam kasus ini adalah Provinsi Jawa Barat. Provinsi Jawa Barat sebagai provinsi dengan jumlah penduduk terbesar di Indonesia, mempunyai potensi yang sangat besar terjadinya berbagai ancaman maupun kasus-kasus perdagangan orang. Jawa Barat merupakan sending area dalam hal kasus perdagangan orang. Sekitar 60 persen korban human trafficking berasal dari Jawa Barat ${ }^{3}$.

\footnotetext{
${ }^{2}$ Ibid., hal : 5-6)

3 Arrahman.com. $60 \%$ Korban Human Trafficking Berasal dari Jabar. 25 Januari 2014. http://www.arrahmah.com
} 
Salah satu Kabupaten di Provinsi Jawa Barat yang memiliki permasalahan trafficking terbesar adalah Kabupaten Cianjur. Ini menjadi menarik karena Kabupaten Cianjur merupakan daerah yang memiliki falsafah hidup yang cukup relijius. Berdasarkan advokasi dari Lembaga Pemberdayaan dan Penguatan Aspirasi Sosial (Lepas), Kabupaten Cianjur menduduki peringkat ketiga di Jawa Barat dalam kasus Human trafficking ${ }^{4}$.

Data yang dikeluarkan oleh Kepala Bidang Advokasi dan Penanganan Kasus Pusat Pelayanan Terpadu Pemberdayaan Perempuan dan Anak (P2TP2A) terkait kasus perdagangan orang (Human Trafficking) di Kabupaten Cianjur dimana pada tahun 2011 terdapat 8 kasus, Tahun 2012 terdapat 12 kasus, dan tahun 2013 hanya terdapat 17 kasus. Dari data tersebut terlihat terjadi peningkatan yang signifikan pada kasus trafficking di Kabupaten Cianjur setiap tahunnya.

Hal berbeda disampaikan oleh Kepala Bagian Pemberdayaan Perempuan Sekretariat Daerah (Setda) Kabupaten Cianjur. Pihaknya mencatat sepanjang tahun 2010 hingga 2013 setidaknya ada 80 kasus trafficking pada perempuan. Dimana pada tahun 2010 tercatat sebanyak 15 kasus saja, dan itu merupakan angka tertinggi sepanjang tahun 2010-

${ }^{4}$ Beni Bastiandy. Cianjur Lumbung Kasus Perdagangan Manusia. 2 Januari. 2014. http://m.inilah.com
$2013^{5}$. Sehingga jika pada tahun 2010 sebagai tahun tertinggi terjadinya kasus trafficking maka terdapat ketimpangan data antara P2TP2A dan BKBPP, karena data yang dikeluarkan oleh P2TP2A adalah sebanyak 17 kasus pada tahun 2013.

Pemerintah Kabupaten Cianjur mengeluarkan kebijakan-kebijakan sebagai political will untuk menanggulangi perdagangan orang. Salah satunya adalah dengan dibuatnya Peraturan Daerah No 03 Tahun $2010 \quad$ Tentang Penanggulangan Perdagangan Orang. Selain itu Kepala Badan Keluarga Berencana dan Pemberdayaan Perempuan (BKBPP) Kabupaten Cianjur mengatakan bahwa penanganan kasus trafficking dilakukan dengan membentuk tim Gugus Tugas yang terdiri dari P2TP2A, Kepolisian, dan OPD (Organisasi Perangkat Daerah) Terkait Lingkungan Pemerintah Kabupaten Cianjur. Pemerintah Kabupaten bersama P2TP2A Kabupaten Cianjur juga gencar mensosialisasikan pencegahan Human Trafficking kepada semua kalangan masyarakat, termasuk ke setiap OPD (Organisasi Perangkat Daerah). Hal itu dilakukan untuk menyamakan persepsi agar dapat menekan meningkatnya kasus

\footnotetext{
${ }^{5}$ Esih Sukaesih Karo. Perkosaan Terhadap Anak di Kabupaten Cianjur Terus Terjadi. 5 Januari 2014. metrotvnews.com. Editor Patna Budi Utami.
} 
Human Trafficking di Kabupaten Cianjur.

Upaya ini nampaknya masih belum mendapatkan hasil yang maksimal, pasalnya implementasi Peraturan Daerah No. 03 tahun 2010 tentang Penanggulangan Perdagangan Orang di Kabupaten Cianjur belum bisa menghentikan permasalahan ini. Bahkan seiring berjalannya waktu, bentuk kejahatan tindak pidana perdagangan manusia atau human trafficking semakin berkembang. Hasil review (evident base monitoring) Perda Nomor 3/2010 yang dilaksanakan Konsorsium Pengembangan Politik Perempuan di Jawa Barat tergabung dalam Lembaga Advokasi Kerakyatan (LAK) dan LSM Binangkit dibantu Yayasan Lembaga Pemberdayaan dan Penguatan Aspirasi Sosial (Lepas) menyimpulkan, kinerja pelaksanaan Perda Nomor 3/2010 masih berada pada kategori rendah, pasalnya belum maksimalnya penanganan trafficking dan belum sepaham antara pemerintah dan masyarakat menjadi sebab mengapa peraturan daerah ini harus segera ditinjau ulang ${ }^{6}$.

berupa pembuatan strategi, kebijakan, program, dan kegiatan yang terencana atau dengan kata lain membiarkan sebuah kebijakan mengalir begitu saja tanpa ada

${ }^{6}$ Menurut Susanne Febrianti dalam Beni, Bastiandy. Perda Trafficking Cianjur tak Efektif. 14 januari 2014. http://m.inilah.com. pembaharuan, pasti akan berdampak negatif. Selain itu dengan tindak penanganan yang setiap tahunnya sama, tanpa memprediksi kondisi yang selalu berubah dan tanpa mengantisipasi faktor-faktor pendukung lainnya, maka dapat diprediksi suatu saat permasalahan ini akan seperti bom waktu yang siap meladak kapan saja. Dengan kata lain dimungkinkan permasalahan trafficking yang ada di Kabupaten Cianjur akan jauh lebih besar kedepannya.

Tanggung jawab bersama menjadi modal dalam penanggulangan perdagangan orang, hal ini bisa diturunkan melalui program, kegiatan, ataupun yang lainnya. Terlihat dari sosialisasi yang dilakukan oleh pemerintah daerah nampaknya belum cukup untuk membangun sebuah kesadaran kolektif baik antar OPD (Organisasi Perangkat Daerah) dan masyarakat. Sehingga permasalahan trafficking dapat diselesaikan dan menjadi permasalahan bersama dan bukan hanya menjadi tanggungjawab P2TP2A saja.

Jika semua pihak yang terkait untuk melakukan penanggulangan perdagangan orang, baik itu pemerintah, swasta dan masyarakat telah sadar terhadap bentuk dan dampak dari permasalahan ini, serta ditopang oleh penegakan hukum yang baik maka tidak menutup kemungkinan akan menggeser peringkat Kabupaten Cianjur sebagai 
peringkat ketiga dalam kasus perdagangan manusia di Provinsi Jawa Barat. Sehingga dibutuhkan peran Gugus Tugas yang ada, dan tidak melimpahkan penanganan dan pencegahan trafficking hanya pada P2TP2A saja.

Dari permasalahan tersebut, perlu kiranya membuat sebuah analisis terkait kebijakan-kebijakan yang dikeluarkan untuk memberantas kejahatan trafficking perempuan. Analisis kebijakan menghasilkan dan menyajikan informasi sedemikian rupa sehingga dapat memberikan landasan dari para pembuat kebijakan dalam membuat keputusan. Selain itu analisis kebijakan dapat melihat kesesuaian isi dari sebuah kebijakan dalam menyelesaikan permasalahan yang ada. Sehingga dari analisis kebijakan itulah dapat ditelusuri apa dan bagaimana sesungguhnya trafficking perempuan itu, lalu dapat juga ditelusuri faktor penyebab peningkatan jumlah pada kasus trafficking di Kabupaten Cianjur dan upaya yang telah dilakukan pemerintah untuk mencegah terjadinya trafficking perempuan di Kabupaten Cianjur.

Berdasarkan permasalahan yang telah diuraikan di atas, mendorong penulis untuk melakukan sebuah penelitian dengan judul: Analisis Kebijakan Pemerintah Tentang Pencegahan dan Penanganan Korban Perdagangan
(Trafficking) Perempuan dan Anak Di Kabupaten Cianjur.

\section{TINJAUAN PUSTAKA}

\section{Kebijakan Publik dan Analisis}

\section{Kebijakan}

Dalam mengatasi permasalahan perdagangan orang, khususnya yang menyangkut pencegahan dan penanganan korban perdagangan perempuan dan anak, diperlukan sebuah kebijakan untuk mangaturnya. Kebijakan ini adalah kebijakan yang menyangkut orang banyak. Kebijakan adalah sebuah keputusan politis yang diambil oleh pemerintah sebagai bagian dari sikap pemerintah untuk memecahkan sebuah persoalan publik.

Pada prinsipnya sebuah kebijakan tidak terlepas dari keterlibatan seluruh element yang ada baik itu masyarakat sebagai bagian yang terikat dalam hasil putusan kebijakan sampai pada tahap pemerintah sebagai badan pembuat kebijakan tersebut. Kebijakan memiliki beragam definisi, yang masing-masing memiliki penekanan berbeda, hal ini tidak terlepas dari latar belakang seorang ilmuan tersebut. Namun demikian, satu hal yang perlu diingat dalam mendefinisikan kebijakan, adalah bahwa pendefinisian kebijakan tetap harus mempunyai pengertian mengenai apa yang sebenarnya dilakukan, ketimbang apa yang diusulkan dalam tindakan mengenai 
suatu persoalan tertentu. (Winarno, $2012: 21$ )

Thomas R. Dye mendefinisikan bahwa kebijakan publik itu adalah "kebijakan merupakan pilihan-pilihan apapun oleh pemerintah, baik untuk melakukan sesuatu maupun untuk tidak melakukan sesuatu (whatever government choose to do or not to do) (Winarno, 2009 : 17). Menurut Thomas R. Dye pula $(1995,2)$ dalam buku yang berbeda definisikan kebijakan publik adalah sebagai segala sesuatu yang dikerjakan pemerintah, mengapa mereka melakukan, dan hasil yang membuat sebuah kehidupan bersama tampil berbeda (what government do, why they do it, and what difference it makes). (Nugrogo, 2009 : 93-101)

Menurut Rian Nugroho, kebijakan (policy) adalah an authoritative decision. Decision made by the one hold the outhoriy, formal and informal. Publik adalah sekelompok orang yang terikat dengan suatu isu tertentu. Jadi, "publik bukanlah umum, rakyat, masyarakat, maupun sekedar stakeholders. Publik adalah a sphere where people become citizen, a spece where citizens interact, where state and society exist". Jadi kebijakan publik adalah, any state of or Goverment (as the hold of the authority) decision to manage public life (as the sphere) in order to reach themition of the nation (remenber, nation is consist of two institutions: state and societ). Secara sederhana dapat dikatakan bahwa kebijakan publik adalah:

...setiap keputusan yang dibuat oleh negara, sebagai strategi untuk merealisasikan tujuan dari negara. Kebijakan publik adalah strategi untuk mengantarkan masyarakat pada masa awal, memasuki masyarakat pada masa transisi, untuk menuju masyarakat yang dicitacitakan. (Nugroho, 2009:96).

Salah satu kebijakan yang dikeluarkan oleh pemerintah untuk mengatasi permasalahan publik yang terjadi saat ini adalah kebijakan mengenai pencegahan dan penanganan korban perdagangan (trafficking) perempuan dan anak. Kebijakan yang dikeluarkan memiliki tahap yang berbeda, dari tingkat pusat sampai daerah. Oleh karena itu penting kiranya mengetahui arah sebuah kebijakan dan dampak dari sebuah kebijakan tersebut dengan melakukan analisis terhadap kebijakan tersebut.

Menurut William N. Dunn bahwa yang dimaksud dengan analisis kebijakan adalah:

Aktivitas intelektual dan praktis yang ditujukan untuk menciptakan, secara kritis menilai, dan mengkomunikasikan pengetahuan tentang dan dalam proses kebijakan. Analisis kebijakan adalah disiplin ilmu sosial terapan yang menggunakan berbagai metode pengkajian multiple 
dalam konteks argumentasi dan debat politik untuk menciptakan secara kritis menilai dan mengkomunikasikan pengetahuan yang relevan dengan kebijakan, analisis kebijakan adalah aktivitas intelektual yang dilakukan dalam proses politik. Analisis kebijakan tidak dimaksudkan menggantikan politik dan membangun elite teknokratis. Analisis kebijakan diletakkan pada konteks sistem kebijakan. (dalam Nugroho, 2009 : 269-270)

Pandangan lain disampaikan oleh E.S Quade, mantan Kepala Departemen Matematika di Perusahaan Rand yang dikutip oleh William N. Dunn, menyajikan dasar untuk mendefinisikan analisis kebijakan. Analisis kebijakan adalah:

Suatu bentuk analisis yang menghasilkan dan menyajikan informasi sedemikian rupa sehingga dapat memberikan landasan dari para pembuat kebijakan dalam membuat keputusan.... (Dunn, 2003 : 95-96).

Sehingga dapat dikatakan bahwa analisis kebijakan adalah aktivitas intelektual dan praktis yang ditujukan untuk menciptakan, secara kritis menilai, dan mengkomunikasikan pengetahuan tentang dan dalam proses kebijakan baik secara formal maupun informal yang menghasilkan dan menyajikan informasi sedemikian rupa sehingga dapat memberikan landasan bagi para pembuat kebijakan dalam membuat keputusan.

Analisis kebijakan itu dapat dilakukan sebelum atau setelah kebijakan diimplementasikan, menurut William N. Dunn berpendapat bahwa:

Prediksi secara khusus digunakan sebelum suatu tindakan diadopsi (ex ante), sedangkan deskripsi dan evaluasi lazimnya dilakukan setelah suatu tindakan berlangsung (ex post). Prediksi dan preskripsi berhubungan dengan masa depan, sementara deskripsi dan evaluasi berhubungan dengan masa lalu (Dunn, 2003 : 100-101).

Penelitian ini mengarah pada analisis retrospektif atau ex post, dimana analisis ini dilakukan setelah aksi kebijakan dilakukan. Analisis kebijakan diambil dari berbagai macam disiplin ilmu dengan tujuan memberikan informasi yang bersifat: deskriptif, evaluatif, dan/atau preskriptif. Analisis kebijakan menjawab tiga macam pertanyaan, yaitu:

1. Nilai yang pencapaiannya merupakan tolak ukur utama untuk menilai apakah suatu masalah sudah teratasi?

2. Fakta yang keberadaannya dapat membatasi atau meningkatkan pencapaian nilai-nilai.

3. Tindakan yang penerapannya dapat menghasilkan pencapaian nilai-nilai. (Dunn, 2000 : 97) 
Untuk menjawab analisis kebijakan dapat menggunakan salah satu atau kombinasi dari ketiga pendekatan analisis ini: empiris, evaluatif, dan/atau normatif. Pendekatan tersebut dipaparkan dalam tabel sebagai berikut.

Tabel 1 Pendekatan Analisis Kebijakan

\begin{tabular}{|l|l|l|}
\hline Pendekatan & Pertanyaan Utama & Tipe Informasi \\
\hline Empiris & Adakah dan akankan ada (fakta) & Deskriptif dan Prediktif \\
\hline Normatif & Apa manfaatnya (nilai) & Evaluatif \\
\hline Evaluatif & Apakah yang harus diperbuat (aksi) & Preskriptif \\
\hline
\end{tabular}

(Willian N. Dunn, 2000 : 98)

Tabel di atas dapat menjelaskan bahwa pendekatan empirik atau empiris akan berbicara mengenai realitas-relaitas kebijakan yang terjadi atau menerangkan dan menunjukkan fakta-fakta yang terjadi baik pada tahap implementasi dan atau evaluasi kebijakan. Realitasrealitas ini berupa fakta yang akan disajikan dalam bentuk deskriptif atau presdiktif.

\section{Perdagangan Orang}

Definisi trafficking menurut Keputusan Presiden (Keppres) RI No. 88 Tahun 2002 tentang Rencana Aksi Nasional Penghapusan Perdagangan (trafiking) Perempuan dan Anak yang diadopsi dari pasal 3 protokol perdagangan orang (Palermo Protocol), yaitu:

a. "Perdagangan (trafiking) manusia" adalah rekrutmen, transformasi, pemindahan, penyembunyian atau penerimaan seseorang dengan ancaman atau penggunaan kekerasan, penculikan pemalsuan, penipuan, penyalahgunaan atau posisi rentan atau memberi bayaran atau manfaat sehingga memperoleh persetujuan dari orang yang memegang kendali atas orang lain tersebut, untuk kepentingan eksploitasi yang secara minimal termasuk eksploitasi lewat prostitusi atau bentuk-bentuk eksploitasi seksual lainnya, kerja atau pelayanan paksa, perbudakan atau praktekpraktek lain yang serupa dengan perbudakan, penghambaan, atau pengambilan organ-organ tubuh;

b. Ijin dari seorang korban perdagangan manusia untuk maksud eksploitasi sebagaimana termaktub dalam sub paragraf (a) pasal ini menjadi tidak relevan dimana segala yang disebutkan dalam sub paragraf (a) telah digunakan; 
c. Perekrutan, transportasi, transfer, penyembunyian atau penerimaan seorang anak untuk tujuan eksploitasi akan dianggap sebagai "trafiking (perdagangan) manusia" bahkan apabila hal tersebut tidak melibatkan cara-cara sebagaimana dipaparkan dalam sub paragraph (a) dari pasal ini; d. "Anak" adalah setiap orang yang berusia di bawah usia 18 tahun.

Dari definisi di atas maka kita dapat melihat berbagai bentuk eksploitasi yang dilakukan, baik secara seksual ataupun tenaga kerja dan atau yang lainnya. Data yang dirilis oleh ELSAM (2005), menjelaskan bentuk-bentuk eksploitasi:

Tabel 2 Bentuk-Bentuk Eksploitasi dan Pengertiannya

\begin{tabular}{|c|l|}
\hline BENTUK & \multicolumn{1}{|c|}{ PENGERTIAN } \\
\hline $\begin{array}{c}\text { Eksploitasi } \\
\text { Seksual }\end{array}$ & $\begin{array}{l}\text { Mereka yang terlibat dalam kegiatan prostitusi, pelayan } \\
\text { pekerja seks, atau menjadi objek kegiatan pornografi yang } \\
\text { dikarenakan oleh ancaman pemaksaan, penculikan, } \\
\text { diperlakukan dengan salah, menjadi orang yang dijual (debt } \\
\text { bondage) atau menjadi korban penipuan. Adapun pengertian } \\
\text { ekspolitasi seksual adalah menurut Peraturan Daerah } \\
\text { Kabupaten Cianjur no 03 tahun 2010 adalah, segala bentuk } \\
\text { pemanfaatan organ tubuh seksual atau organ tubuh lain dari } \\
\text { korban untuk mendapatkan keuntungan termasuk tetapi tidak } \\
\text { terbatas pada semua kegiatan pelacuran atau pencabulan (Bab } \\
\text { 1 Pasal 1 Angka 20) }\end{array}$ \\
\hline $\begin{array}{c}\text { Kerja Paksa } \\
\text { Forced Labour) }\end{array}$ & $\begin{array}{l}\text { Segala bentuk pekerjaan atau pelayanan yang didapat } \\
\text { (pelaku) dengan menggunakan tenaga orang yang berada di } \\
\text { dalam ancaman hukuman dan orang tersebut bekerja } \\
\text { melayani tanpa keinginannya sendiri secara sukarela. }\end{array}$ \\
\hline Perbudakan & $\begin{array}{l}\text { Keadaan (status) dan kondisi seseorang terhadap siapa hal } \\
\text { pemilih (dari orang lain) diberlakukan terhadapnya. }\end{array}$ \\
\hline $\begin{array}{c}\text { Penghambaan } \\
\text { (Serfdom) }\end{array}$ & $\begin{array}{l}\text { Yakni status atau kondisi orang (-orang) yang berdiam di atas } \\
\text { tanah milik orang lain yang menurut hukum kebiasaan atau } \\
\text { perjanjian terikat untuk hidup dan bekerja di atas tanah } \\
\text { tersebut dan wajib mengabdi pada orang tersebut, baik } \\
\text { dengan imbalan maupun tidak dan ia tidak bebas mengubah } \\
\text { statusnya itu. }\end{array}$ \\
\hline $\begin{array}{c}\text { Trafficking dan pengambilan organ-organ tubuh hanya } \\
\text { muncul jika seseorang dipindahkan untuk tujuan pemindahan } \\
\text { organ-organ } \\
\text { tubuh }\end{array}$ & $\begin{array}{l}\text { pemindahan organ (organ yang dipindahkan sudah tidak } \\
\text { berada dalam tubuh lagi). }\end{array}$ \\
\hline
\end{tabular}

(dalam Valentina Sagala dan Ellin Rosana, 2007 : 21) 
Selain itu ada beberapa bentuk perdagangan manusia yang sering kali terjadi pada perempuan dan anak-anak ${ }^{7}$ :

1. Kerja Paksa Seks \& Eksploitasi seks.

2. Pembantu Rumah Tangga (PRT)

3. Bentuk Lain dari Kerja Migran

4. Penari, Penghibur \& Pertukaran Budaya

5. Pengantin Pesanan

6. Beberapa Bentuk Buruh/Pekerja Anak

7. Trafficking/penjualan Bayi

8. Kawin Kontrak

Faktor terjadinya trafficking sebagaimana sudah dilakukan oleh United Nations Global Initiative to Fight Human Trafficking adalah:

Kekerasan berbasis gender; praktek-praktek

ketenagakerjaan yang diskriminatif; struktur sosial yang patriarkal; memudarnya jaringan ikatan keluarga; marginalisasi etnik, ras dan agama; pemerintah yang korup dan gagal; persoalan status (sebagai warga negara atau penetap legal yang berkaitan dengan kerja); peran dan posisi perempuan dalam keluarga; hirarki kekuasaan dan tertib sosial; tanggung jawab dan peran anak-anak; menikah dini tingginya laju perceraian dan

http://counterwomentrafficking.blogspot.co $\mathrm{m}$

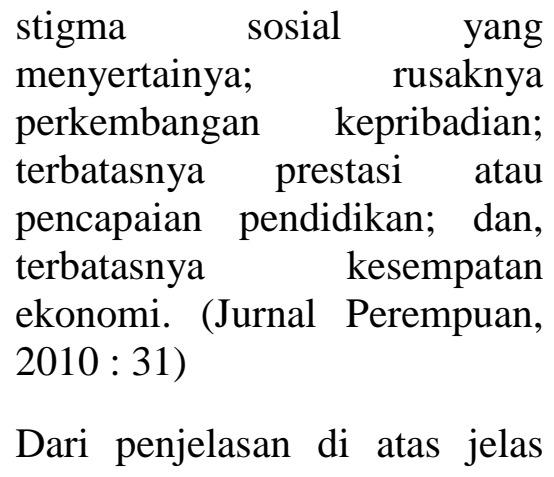
bahwa betapa peliknya persoalan trafficking, kerena ini bukan hanya berbicara mengenai faktor "kemiskinan" semata. Melaikan juga pada bagaimana faktor lingkungan baik itu keluarga, pemerintah maupun strukur sosial berkaitan satu sama lain terhadap praktek trafficking ini. Namun anggapan bahwa kemiskinan adalah sesuatu yang faktor penyebab trafficking, tidak sepenuhnya salah.

Orang-orang miskin di negaranegara berkembang, tidak memiliki banyak pilihan dalam hidupnya, dan karenanya mereka seolah-olah "dipaksa" untuk meninggalkan kampung halaman atau komunitasnya dalam rangka untuk bertahan hidup atau untuk mencari kesempatan yang lebih baik secara ekonomi di tempat atau negara lain. Merujuk pada laporan United Nations Development Index, menyatakan bahwa ternyata negaranegara asal korban trafficking justru berasal dari negara-negara tingkat menengah dan bukan menjadi target utama dari korban trafficking yang diduga semula. (Jurnal Perempuan, $2010: 32$ ) 


\begin{abstract}
Selain kemiskinan terdapat faktor trafficking yang berkaitan dengan dimensi gender, hal ini mendapat sorotan dari Kamala Kempado, asisten professor kajian wanita dan sosiologi di University of Colorado, Boulder, ia mangatakan bahwa:
\end{abstract}

Perempuan terepresentasikan secara tidak profesional diantara kalangan miskin, tidak terdokumentasikan, terlilit utang, dan tenaga kerja Internasioanal. Sementara itu dunia saat ini sangat diwarnai dengan diskriminasi dan misogini yang sangat memiliki dampak pada kehidupan perempuan, dan membatasi ekonomi mereka. Ini artinya perempuan suka atau tidak suka harus selalu berhubungan dengan tata dunia yang berbasis rasial dan bias gender dalam berimigrasi untuk mencari pekerjaan dengan upah yang lebih baik. (Jurnal Perempuan, $2010: 32$ )

Hal ini seolah menjadi bahan pertimbangan penyebab tingginya angka perdagangan manusia yang menimpa pada pemempuan. Perempuan dan anak seolah menjadi target utama dalam operasi ini, karena merujuk pada laporan yang dibuat oleh United Nations Office on Drugs and Crime (UNODC) mengungkapkan bahwa pada tahun 2006, dari setidaknya 136 negara yang melaporkan adanya korban perdagangan perempuan, dua pertiga dari korban tersebut adalah perempuan (Jurnal Kriminologi Indonesia, 2011 : 308). Atau data yang dirilis pada tahun 2011, setidaknya ada 90,3\% korban tindak pidana perdagangan orang adalah perempuan dan $23,6 \%$ nya adalah anak-anak.

\section{METODE PENELITIAN}

Metode yang digunakan dalam penelitian ini adalah metode penelitian kualitatif, karena dianggap oleh peneliti memiliki karakteristik yang sesuai dengan permasalahan yang ada. Penelitian ini berangkat dari permasalahan sosial, permasalahan yang ada di masyarakat dan berkembang setiap waktunya. Dengan metode kualitatif maka penelitian ini akan bersifat fleksible atau dapat beradaptasi dengan perubahan-perubahan yang ada.

Metode kualitatif merupakan metode yang merujuk ke prosedur penelitian yang menghasilkan data deskriptif. Istilah "deskriptif" berasal dari bahasa Inggris to describe yang berarti memaparkan atau menggambarkan sesuatu hal, misalnya keadaan, kondisi sosial, peristiwa, kegiatan, dan lain-lain. Dengan demikian yang dimaksudkan dengan penelitian deskriptif adalah Penelitian yang dimaksudkan untuk menyelidiki keadaan, kondisi atau hal lain-lain yang sudah disebutkan. Dalam hal ini peneliti hanya memotret apa yang terjadi pada diri 
objek atau wilayah yang diteliti, kemudian memaparkan apa yang terjadi dalam bentuk laporan penelitian secara lugas (Arikunto, $2010: 3)$.

Adapun teknik pengumpulan data yang digunakan dalam penelitian ini adalah sebagai berikut:

1. Studi pustaka, yaitu pengumpulan data yang bersumber pada buku-buku, literatur, serta peraturan perundang-undangan yang memiliki relevansi dengan topik tersebut.

2. Studi lapangan, yaitu dengan cara mengumpulkan data dan menyeleksi data yang diperoleh dilokasi penelitian

3. Interview (wawancara), adalah proses memperoleh keterangan untuk tujuan penelitian dengan cara tanya jawab sambil bertatap muka antara pewawancara dengan informan atau orang yang diwawancarai, dengan atau tanpa menggunakan pedoman (guide) wawancara, di mana pewawancara dan informan terlibat dalam kehidupan sosial yang relatif lama (Bungin, 2007 : 108). Melalui wawancara peneliti berharap dapat mengetahui permasalahan secara lebih mendalam dengan jumlah responden yang sedikit/kecil, wawancara ini berbentuk tidak terstruktur dan dapat dilakukan melalui tatap muka (face to face) maupun dengan telepon (Sugiono, 2010 : 138140).

4. Dokumentasi, yaitu pengambilan data yang diperoleh melalui dokumendokumen tertentu. Dokumen bisa berbentuk tulisan, misalnya catatan harian, sejarah kehidupan, cerita, biografi, peraturan serta kebijakan yang sesuai dan berkaitan dengan penelitian ini.

Hal yang juga pentin dalam metode penelitian adalah Informan. Melalui informan kita dapat menggali dan mempertanyakan sebuah permasalahan penelitian. Dalam memperoleh informan peneliti haruslah hati-hati, tidak merujuk langsung pada salah satu orang yang "dianggap" memahami pemasalahan, tetapi mata dan telinga harus dibuka lebar-lebar sehingga memang menentukan subjek yang memang paling tahu tentang variabel yang diteliti. Menurut Moleong (1998), penentuan informan yang lain juga harus hati-hati yaitu harus purposive, seimbang dengan tujuan dan hakekat penelitian kualitatif, responden harus subjek yang betulbetul tahu tentang masalah yang dikehendaki dan dapat dipercaya oleh peneliti. Dalam penelitian ini maka yang dijadikan narasumber adalah Ketua Komisi IV DPRD Kabupaten Cianjur; Asisten Daerah Bidang Kesejahteraan Masyarakat 
Sekretaris Daerah; Bidang Pelayanan Umum P2TP2A; Kepala Sub Bidang Pemberdayaan Perempuan BKBPP; Ketua LSM Lepas; Pelaku (Trafficker); Kepala Sub Bidang Ketenagakerjaan Dinsosnakertrans.

Untuk pengolahan dan analisa data, penulis menggunakan tahapan seperti yang dikemukakan oleh Sugiono yang mengutip pendapat Miles and Huberman dimana terdapat tiga tahap proses analisis data yaitu: Data Reduction (reduksi data), Data display (tahap penyajian data), Conclution Drawing (Verifikasi). (Sugiono, 2010 : 247253)

\section{HASIL DAN PEMBAHASAN}

Salah satu pelanggaran terhadap Hak Asasi Manusia adalah perdagangan orang atau trafficking. Trafficking menjadi salah satu contoh pelanggaran terhadap Hak Asasi Manusia, karena trafficking bertujuan untuk mengeksploitasi atau menyebabkan orang tereksploitasi. Pemerintah Kabupaten Cianjur pada tahun 2010 mengeluarkan peraturan daerah sebagai bentuk penghormatan, pengakuan dan perlindungan terhadap hak asasi manusia. Sejak pembentukannya, hingga saat ini perdagangan manusia di Kabupaten Cianjur masih menjadi persoalan. Pemerintah perlu mendapatkan informasi terkait gambaran dan evaluasi terhadap kebijakan yang telah dikeluarkan.
Gambaran dan evaluasi yang dilakukan dapat dijadikan sebagai bahan pertimbangan untuk memilih tindakan atau alternatif kebijakaan yang dapat dilakukan untuk mengatasi masalah perdagangan manusia tersebut.

Analisis kebijakan hadir sebagai proses untuk memproduksi dan mentransformasi pengetahuan atau informasi yang relevan dengan kebijakan yang telah ada. Melalui analisis kebijakan seorang analis dapat menghasilkan informasi dan argumentasi terhadap kebijakan tersebut. Sehingga dengan menganalisis kebijakan yang telah dikeluarkan oleh Pemerintah Kabupaten Cianjur dalam penanggulangan perdagangan orang, maka analis akan mendapatkan jawaban atas tiga pertanyaan. Pertanyaan yang dapat dijawab melalui analisis kebijakan menurut Dunn adalah dengan melihat fakta, nilai dan tindakan dari kebijakan penanggulangan perdagangan orang yang dilakukan oleh pemerintah. Adapun fakta, nilai dan tindakan tentang pencegahan dan penanganan korban perdagangan (trafficking) perempuan dan anak di Kabupaten Cianjur, adalah sebagai berikut:

\section{Fakta dalam Pencapaian Nilai tentang Pencegahan dan Penanganan Korban Perdagangan (Trafficking) Perempuan dan Anak di Kabupaten Cianjur}

Fakta merupakan realitas atau empiris untuk menjelaskan sebab dan 
akibat dari suatu kebijakan. Fakta menjelaskan kenyataan yang terjadi dilapangan, baik yang keberadaannya dapat meningkatkan atau membatasi pencapaian tujuan dari sebuah kebijakan. Fakta yang terjadi dilapangan dapat dijadikan sebagai dasar untuk menilai apakah kebijakan yang telah dikeluarkan telah berhasil atau tidak.

Pemerintah telah memiliki political will dengan mengeluarkan peraturan-peraturan sebagai payung hukum bagi penanggulangan perdagangan orang di Kabupaten Cianjur. Adapun peraturan-peraturan tersebut antara lain:

Tabel 3 Daftar Kebijakan Pemerintah Kabupaten Cianjur di Bidang Pemberdayaan Perempuan dan Anak

\begin{tabular}{|c|c|c|c|c|}
\hline No & Kebijakan & Nomor Keputusan & $\begin{array}{c}\text { Tanggal } \\
\text { Penetapan }\end{array}$ & Keterangan \\
\hline 1 & Pembentukan P2TP2A & $\begin{array}{ll}\text { Nomor } & \text { 463/Kep.113- } \\
\text { Ks/2009 }\end{array}$ & 03 Juni 2009 & $\begin{array}{l}\text { Keputusan } \\
\text { Bupati }\end{array}$ \\
\hline 2 & $\begin{array}{l}\text { Pembentukan Gugus } \\
\text { Tugas pencegahan dan } \\
\text { Penanganan Tindak } \\
\text { Pidana Perdagangan } \\
\text { Orang }\end{array}$ & $\begin{array}{ll}\text { Nomor } & 182 / \text { Kep.124- } \\
\text { Ks/2009 }\end{array}$ & 17 Juni 2009 & $\begin{array}{l}\text { Keputusan } \\
\text { Bupati }\end{array}$ \\
\hline 3 & $\begin{array}{l}\text { Penanggulangan } \\
\text { Perdagangan Orang }\end{array}$ & Nomor 03 Tahun 2010 & $\begin{array}{ll}19 & \text { Februari } \\
2010 & \end{array}$ & $\begin{array}{l}\text { Peraturan } \\
\text { Daerah }\end{array}$ \\
\hline 4 & $\begin{array}{l}\text { Petunjuk Pelaksanaan } \\
\text { Peraturan Daerah No } \\
03 \quad \text { Tahun } 2010 \\
\text { Tentang } \\
\text { Penanggulangan } \\
\text { Perdagangan Orang }\end{array}$ & Nomor 49 Tahun 2011 & 15 Maret 2011 & Peraturan Bupati \\
\hline 5 & \begin{tabular}{lr}
\multicolumn{2}{l}{ Penatalaksanaan } \\
Pelayanan & Terpadu \\
Korban & Kekerasan \\
Terhadap & Perempuan \\
dan Anak & di Rumah \\
Sakit di & Kabupaten \\
Cianjur. &
\end{tabular} & $\begin{array}{l}\text { Nomor: } \\
\text { - } 146 / 988 . b / B K B P P \\
\text { - } 2254.1 / \text { KESGA- } \\
\text { GM/X/2011 } \\
\text { - } 445 / 17 / R S U D / 2011 \\
\text { - } 306 / \text { RSC/X/2011 } \\
\text { - } 23 . B / S e k r t / P 2 T P 2 A / K a b . \\
\text { cjr/2011 }\end{array}$ & $\begin{array}{ll}25 & \text { Oktober } \\
2011 & \end{array}$ & $\begin{array}{l}\text { Kesepakatan } \\
\text { Bersama }\end{array}$ \\
\hline
\end{tabular}

Sumber: Sekretariat Daerah Bidang Kesejahteraan Rakyat, Tahun 2014

Dalam Perda yang telah disebutkan diatas terdapat Gugus Tugas yang berfungsi sebagai implementor dari Peraturan Daerah tersebut. Gugus Tugas adalah gabungan antar Organisasi Perangkat Daerah (OPD) dan Lembaga
Swadaya Masyarakat (LSM) yang memiliki peran dalam penanggulangan perdagangan orang.

Salah satu anggota Gugus Tugas yang memiliki peran yang sentral dalam penanggulangan perdagangan orang adalah P2TP2A, 
sebagai pusat layanan yang dibentuk oleh Bupati Cianjur untuk membantu pemerintah dalam melaksanakan program ini. Pada tahap implementasinya P2TP2A diberikan wewenang yang luas baik pada tahap pencegahan ataupun penanganan.

Penanggulangan tindak pidana perdagangan orang yang dilakukan oleh pemerintah dapat dilihat dari sejauh mana kebijakan pemerintah menjangkau faktor-faktor penyebab terjadinya perdagangan orang/trafficking. Banyak faktor penyebab terjadinya trafficking, namun data yang dirilis oleh P2TP2A sebagai pusat pelayanan menyebutkan terdapat 5 faktor perdagangan orang di Kabupaten Cianjur, sebagai berikut:

\section{1) Faktor Geografis.}

Secara geografis luas wilayah Kabupaten Cianjur $350.148 \mathrm{Km} 2$, yang terbagi menjadi 32 Kecamatan, 342 Desa dan 6 Kelurahan. Setiap wilayah mendapatkan prioritas yang sama walaupun karakteristik dan kekhasan nya berbeda. Hal ini didasarkan karena tidak terdapatnya zona merah sebagai kawasan penyumbang trafficking terbesar atau daerah yang berpotensi menjadi target tindak pidana perdagangan orang. Untuk menjangkau 32 Kecamatan tersebut BKBPP hanya memiliki 1 Satgas dari 32 Satgas yang direncanakan. Selain itu sosialisasi yang dilakukan berjumlah 1 kali pada tahun
2011 dan 6 kali pada tahun 2012, dengan memanfaatkan jejaring yang ada dimasyarakat.

Tindakan pemerintah ini mendapat tanggapan wajar dari LSM Lepas dengan berasumsi bahwa :

"Pemerintah tidak akan dapat menjangkau seluruh kawasan yang ada di Cianjur secara mendalam, hal ini disebabkan karena mungkin mereka harus mengerjakan hal-hal lain selain masalah trafficking ini. Pemerintah hanya memberikan instruksi kepada bawahannya tanpa menggali lebih dalam/langsung turun kelapangan"

Program kerja yang dijalankan oleh pemerintah memberikan dampak perubahahan bagi masyarakat, salah satunya adalah meskipun secara kuantitas angka trafficking di Kabupaten Cianjur semakin meningkat setiap tahunnya, akan tetapi hal ini dinggap memiliki dampak positif bagi pemerintah. Pasalnya dengan meningkatnya jumlah korban trafficking, maka semakin banyak orang sadar terhadap program ini dan berani untuk melapor. 
2) Faktor Kurangnya Lapangan Pekerjaan

Data yang dikeluarkan oleh Badan Pusat Statistik Kabupaten Cianjur terdapat 114.146 jiwa penduduk Kabupaten Cianjur yang tidak memiliki pekerjaan pada tahun 2012, dari jumlah angkatan kerja penduduk Kabupaten Cianjur yang pada tahun 2012 sebayak 1.013.648 jiwa. Artinya terdapat $11,26 \%$ penduduk Kabupaten Cianjur yang tidak memiliki pekerjaan. Sedangkan penduduk yang bekerja atau terserap, masih didominasi pada sektor pertanian.

Lapangan pekerjaan penduduk Kabupaten Cianjur di sektor pertanian yaitu sekitar $62.99 \%$. Sektor pertanian merupakan penyumbang terbesar terhadap produk Domestik Regional Bruto (PDRB) yaitu sekitar 42,80\%. Sektor lainnya yang cukup banyak menyerap tenaga kerja adalah sektor perdagangan dan jasa yaitu sekitar 14,60 \% dan pengiriman pembantu $30 \%$.

$30 \%$ angka tenaga kerja yang bekerja di luar negeri disinyalir karena faktor kurangnya lapangan pekerjaan, namun hal ini mendapat bantahan dari Dinas Sosial Tenaga Kerja dan Transmigrasi, karena bagi masyarakat Cianjur bekerja keluar negeri sudah menjadi hal yang lumrah hingga dianalogikan seperti "pergi ke jamban". Masyarakat dengan pendidikan rendah akan menjadikan bekerja keluar negeri sebagai pekerjaan tetap hingga dilakukan berulang kali.

\section{3) Faktor Pengaruh Lingkungan}

Beberapa contoh kasus perdagangan manusia yang terjadi membuktikan bahwa lingkungan memiliki peran sentral yang menyebabkan seseorang terjerat menjadi korban tindak pidana perdagangan orang. adanya tuntutan gaya hidup seolah menjadi kewajiban yang harus terpenuhi. Sifat "gengsi" kepada teman karena tidak dapat memiliki sesuatu yang sama bahkan lebih menjadi salah satu penyebab permasalahan ini. Selain itu untuk mendapatkan sesuatu dengan cara yang instan masih menjadi pilihan bagi sebagian kalangan. Proteksi dari keluarga menjadi hal yang penting. Namun faktanya lingungan terdekat kita memiliki potensi untuk menjadi trafficker atau pelaku perdagangan orang.

\section{4) Faktor Ekonomi, Sosial Budaya}

Setiap tahun angka kemiskinan di Kabupaten Cianjur mengalami penurunan, seperti tabel dibawah ini

9 http://www.gugustugastrafficking.org 
Tabel 4

Persentase Penduduk Miskin Kabupaten Cianjur Tahun 2008-2013

\begin{tabular}{|l|l|l|}
\hline No & Tahun & $\begin{array}{c}\text { Persentase Tingkat } \\
\text { Kemiskinan }\end{array}$ \\
\hline 1 & 2008 & $15,4 \%$ \\
\hline 3 & 2009 & $14,1 \%$ \\
\hline 3 & 2010 & $14,32 \%$ \\
\hline 4 & 2011 & $13,82 \%$ \\
\hline 5 & 2012 & $13,17 \%$ \\
\hline 6 & 2013 & $11 \%$ \\
\hline
\end{tabular}

Sumber : BPS Jawa Barat 2008-2012

Data diatas menunjukan bahwa pada tahun 2010 persentase angka kemiskinan mengalami kenaikan dibandingkan dengan tahun 2009, dimana persentase kenaikannya sebesar $0,31 \%$. Namun pada tahun 2011-2013 persentase angka kemiskinan kian menurun, hingga pada tahun 2013 sebesar $11 \%$. Kendati angka kemiskinan mengalami penurunan setiap tahunnya, namun masih ada $11 \%$ penduduk Kabupaten Cianjur yang tergolong miskin. Ini menjadi pekerjaan rumah bagi pemerintah karena angka kemiskinan merupakan faktor utama perdagangan manusia yang dapat mempengaruhi faktorfaktor lainnya.

Selain faktor ekonomi, faktor sosial budaya menjadi faktor penyebab trafficking/perdagangan manusia. Cianjur dikenal dengan kawasan religius dengan filosofi Cianjur yaitu ngaos, mamaos, dan maenpo. Selain konsep religiusitas yang menjadi sisi positif dari Kabupaten Cianjur, namun terdapat juga sisi negatifnya. Sisi negatif ini dapat dilihat dari masih terdapatnya pemahaman "sumur, kasur, dapur" untuk wanita/perempuan di sebagian kawasan Cianjur.

\section{5) Faktor Pendidikan}

Di Kabupaten Cianjur trafficking rentan terjadi terhadap perempuan dan anakanak. Hal ini dibuktikan dengan data Angka melek hurup yang dikeluarkan oleh BPS Kabupaten Cianjur, melihat sejauh mana perbandingan persentase antara angka melek hurup laki-laki dan angka melek hurup perempuan yang dimulai dari tahun 2007-2012. Secara umum angka melek hurup lakilaki lebih tinggi dari perempuan. Dimana pada tahun 2012 angka melek hurup laki-laki sebesar 99\% sedangkan perempuan sebesar 96,59\%. Ini membuktikan bahwa kemampuan baca tulis laki-laki lebih baik dari pada perempuan. Angka melek huruf tentunya dapat dipengaruhi oleh tingkat pendidikan atau pertisipasi sekolah. 
Selain itu data yang dikeluarkan oleh Pemerintah Kabupaten Cianjur untuk tingkat partisipasi usia sekolah menyebutkan bahwa:

1. Angka Partisipasi Kasar SD/MI Tahun 2000 mencapai 84,52\%

2. Angka Pastisipasi Kasar SMTP mencapai $38,50 \%$

\section{Angka Partisipasi}

Kasar SMTA mencapai $11,98 \%$

Kendati angka melek hurup perempuan mengalami peningkatan, namun partisipasi untuk melanjutkan pendidikan sekolah menengah pertama (SMP) masih rendah. Sehingga rata-rata pendidikan di Kabupaten Cianjur masih di dominasi oleh lulusan Sekolah Dasar (SD) bahkan tidak tamat SD.

Pendidikan adalah sarana untuk memanusiakan manusia, pengembangan pola pikir dan prilaku. Pendidikan dapat meningkatkan nilai atau derajat seseorang baik dalam pekerjaan ataupun lingkungan sosial. Hal ini dapat dilihat dari angka melek huruf dan partisipasi sekolah memberikan gambaran bahwa perempuan dengan tingkat pendidikan yang rendah rentan menjadi korban trafficking, terlebih rata-rata yang menjadi korban trafficking faktanya adalah orang yang berpendidikan rendah tersebut.

5 (lima) faktor di atas merupakan faktor yang disadari pemerintah, karena sesungguhnya masih banyak faktor lain yang menyebabkan trafficking terjadi.

Telah disebutkan sebelumnya bahwa korban trafficking mayoritas terjadi pada perempuan dan anakanak, namun tidak berarti laki-laki tidak dapat menjadi korban trafficking. Untuk mencegah hal tersebut maka langkah yang diambil adalah melalui sebuah kebijakan (Peraturan Daerah). Disebutkan tegas dalam Peraturan Daerah bahwasanya "Langkah dan kebijakan perdagangan orang sebagaimana dimaksud pada ayat (1) adalah melalui program, kegiatan dan pengalokasian dana" (Perda No 03 tahun 2010). Merujuk pada Rencana Aksi P2TP2A yang memuat beberapa point yang dilaksanakan oleh P2TP2A, antara lain:

1. Sosialisasi P2TP2A dan Peraturan PerundangUndangan

2. Advokasi dan Perlindungan Hukum

3. Rekomendasi dan Rujukan

4. Penjemputan Korban

5. Rehabilitasi Kesehatan

6. Konseling

7. Reintegrasi Sosial

8. Peningkatan Ekonomi Melalui Kursus dan Bantuan Modal Usaha

9. Koordinasi dan Jejaring 
9 (sembilan) upaya ini adalah program yang dilaksanakan oleh P2TP2A untuk melakukan penanggunlangan tindak pidana perdagangan orang.

$$
\text { Pengalaman dilapangan }
$$
dibawah ini dapat dijadikan sebagai bahan penilaian khususnya oleh pemerintah, dalam menilai sejauh mana keberhasilan program tersebut. Dibawah ini adalah rangkuman wawancara peneliti dengan salah satu relawan LSM Lepas:

"Salah satu anggota komunitas salon memberikan informasi yang menarik. Ia adalah salah satu relawan LSM Lepas yang sedang melakukan sebuah gerakan pencegahan HIVIAIDS sebagai program Dinas Kesehatan Kabupaten Cianjur. Komunitas ini dilibatkan oleh pemerintah agar lebih mudah menjangkau sasaran utama. Salah seorang relawan menyatakan bahwa "kan pake kita karena ada unsur kepercayaan yang tinggi, kalo sama kita kan mereka (target sasaran) berani buka-bukaan karena sama dan tidak ada unsur kemunafikan. Kalo sama orang lain, silahkan tanya paling juga tersinggung". Maksud dari perkataan ini adalah untuk menggali informasi secara mendalam maka pemerintah harus menggunakan komunikator yang sejenis dengan target sasaran, sehingga informasi akan tergali secara mendalam karena komunikan akan berkata yang sebenarnya terhadap semua hal yang ditanyakan.

Sasaran utama seperti LSL (Lakilaki Seks Laki-laki), Waria, HRM (Lelaki Pembeli Seks) dan pasangan suami istri (baik yang istrinya "jajan" ataupun yang suaminya suka "jajan" diluar) sebagai aspek yang rentan menjadi korban HIV/AIDS mendapatkan beberapa program layanan seperti:

- Diberikan penyuluhan bahaya HIV/AIDS.

- Tes PCT (tes darah) untuk mengetahui terkena IMS (Infeksi Menular Seks) atau tidak.

- Menyebarkan kondom oleh pemerintah untuk mengurangi resiko HIVIAIDS.

- Menyediakan jarum suntik untuk para pemakai narkoba.

Program-program di atas merupakan program yang dibuat oleh pemerintah untuk mengurangi resiko HIV/AIDS. Berhubungan seks dengan siapa saja merupakan salah satu faktor penyebab seseorang terkena HIV/AIDS. Fakta dilapangan menunjukkan permasalahan seks sudah menjadi barang yang murah, dimana saja kita mampu untuk mendapatkannya. Bahkan korban dari kejahatan ini banyak menimpa anakanak.

$X$ (trafficker) mengatakan : "terdapat anak-anak yang datang pada kita (anggota komunitas salon), korban (anak) tersebut berkata "silahkan mau dijadiin apa? saya mau makan, bayar sekolah ga punya uang, silahkan saja saya layani "itu" (seks)". Setelah datang dan memberikan identitas (foto dan nomor handfone) maka pihak $X$ (trafficker) akan menyerap informasi tersebut dan memberitahukan pada teman-teman sesama anggota komunitas salon tersebut, dengan percakapan:

$$
\begin{gathered}
X \text { (trafficker) } \quad: \text { Ada brondong } \\
\text { baru, cakep lagi }
\end{gathered}
$$

X lain (trafficker) : Kenalin dong 
Percakapan di atas merupakan percakapan yang biasa dilakukan oleh anggota komunitas salon yang dapat diidentifikasi sebagai trafficker.

Program pencegahan HIV/AIDS dipandang sebagai program yang memiliki manfaat jangka panjang, selain dapat mengurangi resiko HIV/AIDS di Kabupaten Cianjur, program ini digunakan sebagai langkah untuk memecahkan permasalahan trafficking. Ketua Lepas mengatakan bahwa "dikarenakan mengungkap trafficking itu tidak mudah, sehingga mengharuskan para relawan masuk ke dalam sistem kejahatan tersebut. Salah satu cara yang dilakukan yaitu melalui program pencegahan dan penanganan HIV/AIDS. Melalui program tersebut ternyata ditemukan banyak anak-anak yang menjadi korban trafficking atau dijual belikan. Seperti anak-anak yang berada di Kawasan Puncak Cianjur, dimana mereka bekerja sebagai PSKPSK untuk memenuhi kebutuhan sahwat para "pelanggan". Masuknya pemerintah atau LSM Lepas kedalam sistem tersebut nampaknya belum mendapatkan hasil yang memuaskan, pasalnya hingga saat ini sulit menemukan mafia atau pelaku utamanya. Sehingga saat ini LSM Lepas bekerjasama dengan PKBI (Persatuan Keluarga Berencana Indonesia) untuk mengetahui pelaku utama dari kejahatan ini."

Sumber : Hasil wawancara dengan "X" anggota komunitas salon dan relawan HIV/AIDS.

Informasi di atas memberikan gambaran kepada kita bagaimana sebenarnya masyarakat mendefinisikan trafficking, bahkan
"X" tidak mengetahui bahwa sesungguhnya ia merupakan trafficker.

P2TP2A sebagai salah satu anggota gugus tugas dapat dikatakan sebagai lembaga yang paling serius dalam memberantas tindak pidana perdagangan orang. Karena, BKBPP sebagai ketua harian dalam Gugus Tugas dalam kontribusinya untuk pencegahan dan penanganan tindak pidana perdagangan orang hanya terbatas sebagai lembaga koordinatif, yang mengkoordinasikan unit-unit yang terdapat dalam gugus tugas. Lembaga ini hanya menerima laporan dari setiap unit Gugus Tugas yang ada, untuk selanjutnya dipertanggung jawabkan kepada Kepala Daerah melalui Sekretaris Daerah. Sehingga BKBPP sebagai lembaga teknis tidak memiliki peran untuk melakukan penanggulangan, karena peran dari penanggulangan itu dilakukan oleh Pusat Pelayanan Terpadu Pemberdayaan Perempuan dan Anak (P2TP2A).

Sebagai lembaga koordinasi, implementasi dari setiap program kerja Gugus Tugas berada pada setiap unit-unit yang terkait. Dengan kata lain setiap unit baik pemerintah ataupun non pemerintah, menjadikan program kerja Gugus Tugas tersebut ke dalam Program Kerjanya dalam lingkup Gugus Tugas. Namun nampaknya Gugus Tugas masih dipahami sebagai bagian terpisahkan, dikarenakan setiap unit yang ada menjalankan program kerjanya sesuai dengan tupoksi yang dimiliki. 
Salah satu anggota gugus tugas, Disnakertrans menyatakan "Trafficking itu bukan konteks ketenagakerjaan. Ketenagakerjaan itu terkait Upah Minimum Kerja (UMK), Jam Sostek, ada uang lembur atau tidak. Disnakertrans itu berbicara mengenai industrial saja, bukan masalah trafficking". Pernyataan ini tentunya bertolak belakang dengan paraturan yang ada. Dalam petunjuk pelaksanaan Peraturan Daerah No 03 Tahun 2010 tentang Penanggulangan Perdagangan Orang, terkait dengan ketenagakerjaan mendapatkan porsi yang cukup besar, karena selain bertanggungjawab dalam pencegahan preemtif dan pencegahan preventif, Dinsosnakertrans juga menjadi Kepala Bidang Rehabilitasi Sosial, Pemulangan dan Reintegrasi.

Dari pernyataan diatas kita dapat menilai, bagaimana aparat pemerintah memiliki pemahaman yang sederhana terkait dengan keterlibatannya dalam pengentasan permasalahan ini. Koordinasi anggota Gugus Tugas yang tidak maksimal, tidak hanya berdampak pada mekanisme kerja, namun hal tersebut juga berdampak pada perbedaan data jumlah koban trafficking yang dirilis baik oleh BKBPP maupun P2TP2A.

Jumlah korban menurut BKBPP pada tahun 2011 sebanyak 8 orang, 2012 sebanyak 12 orang dan pada tahun 2013 sebanyak 34 orang. Sedangkan menurut P2TP2A jumlah korban yang tercatat sebanyak 19 orang untuk tahun 2011, 18 orang untuk tahun 2012 dan 48 orang untuk tahun 2013. Perbedaan tersebut seharusnya menjadi sebuah pertanyaan, mengapa dalam satu instansi terdapat data yang berbeda.

Oleh karena hal tersebut sebuah kesepakatan sistem laporan satu pintu dijadikan sebuah solusi, dimana semua unit dalam Gugus Tugas memberikan laporan kepada P2TP2A terlebih dahulu. Namun hal ini menimbulkan pertanyaan baru apakah P2TP2A tidak mengecilkan tugas dan fungsi dari BKBPP sebagai lembaga teknis daerah.

\section{Nilai yang Dicapai Dalam Kebijakan Pemerintah tentang Pencegahan dan Penanganan Korban Perdagangan (Trafficking) Perempuan dan Anak di Kabupaten Cianjur}

Setelah mendapatkan gambaran atau deskripsi fakta dilapangan tentang penganggulangan perdagangan orang yang dilakukan oleh Pemerintah Kabupaten Cianjur, maka langkah selanjutnya adalah menilai pencapaian fakta tersebut. Nilai atau evaluasi yang dilakukan, menunjuk pada hasil dari kebijakan atau program yang telah dilakukan oleh pemerintah dalam penanggulangan perdagangan orang. Sehingga dapat dikatakan bahwa evaluasi adalah proses untuk melihat apakah kebijakan yang dikeluarkan dapat mengatasi permasalahan yang terjadi atau tidak. 
Pada tahun 2010 Yayasan LEPAS (Lembaga Pengembangan dan Penguatan Aspirasi Sosial) berkerja sama dengan Konsorsium Kepemimpinan Politik Perempuan Jabar, melakukan review imlpementasi dari Perda No 03 Tahun 2010. Kendati Perda tersebut baru berjalan selama 2 tahun, namun hal ini dinilai perlu dilakukan, untuk menilai sejauh mana efektifitas dari Perda tersebut. Review ini dilaksanakan selama 2 bulan (Agustus-September 2012) melalui proses wawancara maupun penyebaran angket kepada 180 responden yang terdiri dari 127 perwakilan masyarakat dan 53 responden dari pihak aparatur pemerintah Kabupaten Cianjur. Hasil kesimpulannya menyatakan bahwa pelaksanaan dari Perda No 03 Tahun 2010 ini masih berada pada kategori rendah.

Empat tahun sejak disahkan Perda No 03 Tahun 2010 pada tanggal 11 Februari 2010 dan dua tahun sejak pelasanaan review yang dilakukan oleh Yayasan Lepas, belum mampu untuk memberikan nilai yang sempurna bagi keberhasilan Perda saat ini. Pemerintah Daerah dinilai tidak serius dalam tindak pidana perdagangan orang. Kendati para aparat pemerintah menyatakan Perda ini telah berhasil, namun fakta dilapangan menunjukkan bahwa masih banyak hal yang tidak terantisipasi dan banyak hal yang harus dibenahi dalam penanggulangan perdagangan orang yang terjadi di Kabupaten Cianjur.

Optimalisasi pelaksanaan kebijakan menjadi prasarat agar kebijakan itu berhasil. Patuh dan faham terhadap apa yang telah disepakati bersama, dapat menjadi acuan dalam bertindak. Dalam Program Kerja Gugus Tugas Pencegahan dan Penanganan Tindak Pidana Perdagangan Orang Kabupaten Cianjur, setiap OPD (Organisasi Perangkat Daerah) memiliki tugas dan fungsi yang harus dijalankan. Terdapat tujuan dan taget/output yang harus dicapai.

Bidang pencegahan memiliki tujuan mencegah segala bentuk tindak pidana perdagangan orang. Upaya pencegahan dilakukan melalui media sosialisasi. Dalam hal ini pemerintah sebagai lembaga yang memiliki wewenang / power seharusnya mampu untuk memberikan pemahaman yang sama baik kepada masyarakat maupun kepada sesama anggota Gugus Tugas dalam upaya penanggulangan perdagangan orang. Karena hingga saat ini persamaan persepsi tentang trafficking belum terbentuk. Pemahaman "X" terhadap profesi yang dia jalani saat ini, adalah bukti bahwa pemerintah belum mampu untuk menjangkau semua kalangan.

Bahkan

ketika Dinsosnakertrans memberikan pernyataan trafficking tidak ada kaitannya dengan ketenagakerjaan atau BKBPP sebagai ketua harian 
Gugus Tugas melimpahkan wewenangnya kepada P2TP2A dan atau ketika Bidang Kesejahteraan Rakyat Pemerintah Daerah tidak akan mengetahui tentang permasalahan trafficking dilapangan jika tidak menjadi anggota Gugus Tugas. Ketiga sikap tersebut menjadi bukti bahwa trafficking masih belum menjadi persoalan bersama, dan tanggung jawab dari semua pihak.

P2TP2A sebagai pusat layanan memiliki peran yang terbatas, kendati mereka memegang kendali atas penanganan terhadap persoalan trafficking. Namun pemasalah trafficking bukan hanya milik P2TP2A, semua elemen baik pemerintah, LSM, masyarakat, keluarga memiliki andil dalam penanggulangan perdagangan orang.

Semua sepakat bahwa permasalah perdagangan orang itu seperti fenomena gunung es (Iceberg Fenomenon), dimana pada tingkat puncak hanya sedikit es yang terlihat, namun jika kita melihat ke bawah ternyata jauh lebih banyak es yang terdapat didasarnya. Sama halnya dengan trafficking, jumlah korban yang terdata baik oleh pemerintah ataupun LSM (Lembaga Swadaya Masyarakat) dan atau oleh yang lainnya, tidak dapat dikatakan sebagai jumlah yang mutlak/pasti. Ketika berbicara mengenai trafficking, maka akan berbicara mengenai jaringan atau sindikat. Sehingga ketika 1 trafficker tertangkap maka mata rantai itu belum tentu terputus.
Selain itu selalu dikatakan bahwa faktor utama perdagangan manusia adalah karena ekonomi. Ekonomi menjadi alasan mengapa seseorang mudah untuk menjadi korban trafficking. Jika kita korelasikan dengan Kabupaten Cianjur yang secara statistik mengalami peningkatan dalam aspek pendidikan, ketersediaan lapangan pekerjaan, faktor sosial budaya yang religius, ekonomi yang membaik namun mengapa angka perdagangan manusia masih terus saja meningkat setiap tahunnya.

Hal di atas memberikan pemahaman bahwa keberhasilan sebuah kebijakan tidak hanya dihitung dari besarnya angka statistik yang meningkat namun juga kualitas yang dapat menurunkan kembali angka tersebut. Pemerintah tidak serta merta harus merasa cepat puas dengan peningkatan angka-angka, karena pada sesungguhnya masalah baru yang timbul mungkin akan jauh lebih berat untuk diatasi.

Jika angka kemiskinan kita menurun sebesar $2,17 \%$ pada tahun 2013 tetapi masih ada $11 \%$ penduduk miskin yang berpotensi untuk menjadi korban trafficking. Jika lapangan pekerjaan kita dirasa cukup untuk menyerap tenaga kerja yang banyak, masih ada 970.000 jiwa masyarakat kita yang tidak memiliki pekerjaan sama sekali dan berpotensi untuk menjadi korban trafficking. Jika pendidikan kita diangkap telah berhasil, masih ada 80,23 anak-anak Kabupaten Cianjur yang tidak sekolah dan putus sekolah menjadi 
anak-anak yang berpotensi untuk menjadi korban trafficking.

Bukan angka 0 (nol) yang kita dapatkan sehingga masalah tersebut bukan lagi menjadi persoalan. Namun hanya penurunan sekian persen yang sisanya tentu masih menjadi persoalan. Bukan pula angka-angka yang dianggap telah berhasil itu tidak memiliki potensi untuk menjadi korban trafficking. Perlu diingat bahwa trafficking telah memiliki bentuk yang beragam, dan dapat masuk pada semua lapisan pekerjaan, tentunya dengan catatan memenuhi 3 syarat yang ada yaitu cara, proses dan tujuan. Sehingga dapat disimpulkan bahwa 2.231.107 penduduk Kabupaten Cianjur memiliki potensi yang sama untuk menjadi korban perdagangan orang.

Selain pencegahan yang tak kalah pentingnya adalah penanganan korban trafficking. Penanganan korban trafficking dilakukan dengan berbagai cara, dengan dilakukan penjemputan, rehabilitasi, hingga pemberian pelatihan secara kolektif.

Sehingga dapat disimpulkan pemerintah belum mampu untuk menanggulangi perdagangan orang yang ada di Kabupaten Cianjur baik secara kuantitas maupun kualitas.

3. Tindakan dalam Pencapaian Nilai Tentang Pencegahan dan Penanganan Korban Perdagangan (Trafficking) Perempuan dan Anak di Kabupaten Cianjur

Pemerintah belum berhasil untuk melakukan penanggulangan tindak pidana perdagangan orang baik secara kuantitas maupun kualitas. Hal ini dikarenakan kelemahan pelaksana kebijakan dalam mengimplentasikan kebijakan tersebut, hal-hal yang dapat dilakukan oleh pemerintah untuk meningkatkan pencapaian nilai/tujuan tersebut adalah:

1) Kualitas Sumber Daya Pelaksana

Pemerintah harus memberikan pemahaman yang merata kepada seluruh jajaran pelaksana kebijakan yang dalam hal ini adalah anggota Gugus Tugas. Pemahaman yang diberikan terkait dengan penanggulangan tindak pidana perdagangan orang, selain itu pemahaman terhadap hak, kewajiban, tugas dan fungsi yang dimiliki oleh masing-masing anggota Gugus Tugas. Misalnya dengan mengadakan pertemuan rutin atau sosialisasi dan pengawasan terhadap setiap kinerja dari anggota Gugus Tugas. Sehingga diharapkan anggota Gugus Tugas mengetahui apa yang dapat dilakukan untuk menanggulangi perdagangan manusia yang ada di Kabupaten Cianjur.

2) Adanya evaluasi

Perlu dipahami bahwa evaluasi bukan hanya sekedar pemberian laporan rutin 
terkait jumlah korban, namun

substansi dari evaluasi adalah setiap instansi terkait mampu mengkomunikasikan

kekurangan atau kelebihan terhadap kinerjanya dan kinerja instansi yang lain.

3) Adanya punishment (hukuman)

Gugus Tugas tidak mengatur terkait punishment (hukuman) yang diberikan. Bahkan BKBPP sebagai ketua harian tidak memberikan sangsi terkait pelanggaran yang dilakukan oleh anggotanya. Dampak yang ditimbulkan adalah tidak terdapat kontribusi dan pemahaman yang sama antar sesama anggota Gugus Tugas. Sehingga mereka merasa apa yang dilakukan adalah benar.

4) Perbaikan dalam perumusan program

Pemerintah seharusnya mampu berpikir logis untuk mengukur keberhasilan suatu program. Perbandingan antara jumlah program dan kegiatan harus berbanding lurus dengan tujuan yang ingin dicapai. Misalnya tidak mungkin seluruh kawasan cianjur mengetahui apa itu trafficking, jika hanya 6 kali saja sosialisasi yang diadakan atau hanya 1 satgas yang dibentuk dari 32 kecamatan yang ada.

5) Pemilihan media sosialisasi
Sosialisasi belum dilaksanakan secara massif, oleh karenanya pemerintah dapat menggunakan media cetak atau elektonik untuk membantu dalam mensosialisasikan TPPO kepada masyarakat.

Jika kelima hal tersebut dapat digunakan oleh pemerintah untuk melengkapi kebijakan yang telah ada maka tujuan kebijakan sesungguhnya dapat tercapai.

\section{SIMPULAN DAN SARAN}

\section{Simpulan}

Berdasarkan hasil analisis terhadap Kebijakan Pemerintah Daerah dalam pencegahan dan penanganan perdagangan (trafficking) perempuan dan anak di Kabupeten Cianjur mendapatkan 3 buah jawaban, yaitu:

1. Fakta

- Fakta dilapangan mengatakan bahwa pemerintah telah mengeluarkan beberapa kebijakan sebagai sikap atau political will untuk menanggulangi perdagangan orang yang ada di Kabupaten Cianjur. Seperti telah dibuatnya Peraturan Daerah, Peraturan Bupati, Kesepakatan Bersama, Keputusan Bupati tentang pembentukan P2TP2A dan Gugus Tugas. 
- Keadaan geografi, pendidikan, ekonomi sosial budaya, kurangnya lapangan pekerjaan dan pengaruh lingkungan merupakan faktor yang telah disadari pemerintah menjadi penyebab perdagangan manusia.

- Melalui P2TP2A pemerintah memberikan pelayanan kepada korban trafficking baik sosialisasi, bantuan hukum, kesehatan, konseling, reintegrasi sosial dan sebagainya. Namun trafficking bukan hanya milik P2TP2A, sehingga setiap instansi yang menjadi anggota Gugus Tugas sesuai dengan Perda tahun 2010 membuat program, kegiatan dan pengalokasian dana. Hingga saat ini hanya beberapa instansi saja yang menjalankan amanat ini.

- Gugus Tugas masih menjadi bagian yang terpisah atau setiap instansi masih berjalan sendiri-sendiri. Penyebabnya adalah koordinasi yang tidak berjalan. Koordinasi yang tidak berjalan dengan baik menyebabkan anggota Gugus Tugas tidak menegeti hak, kewajiban, dan tupoksi yang dimiliki sebagai bagian dari Gugus Tugas.

2. Nilai

Pemerintah Daerah Kabupaten Cianjur tidak serius dalam penanggulangan perdagangan orang/trafficking. Pasalnya selain secara kuantitas pemerintah tidak dapat meminimalisir, secara kualitas pemerintah juga belum mampu untuk mengatasinya. Kegagalan pemerintah melakukan penanggulangan perdagangan orang, salah satunya dapat dilihat dari seberapa besar pemerintah mampu untuk mengatasi faktor-faktor yang menyebabkan trafficking. Faktor geografi, ekonomi, kurangnya lapangan pekerjaan, sosial budaya, pendidikan masih memberikan celah bagi tindak pidana ini.

Selain permasalahan yang hubungannnya dengan sasaran utama kebijakan (masyarakat), permasalahan juga timbul pada tingkat pelaksana kebijakan. Pelaksana Kebijakan tidak memahami apa yang menjadi hak, kewajiban, tugas dan fungsi yang dimilikinya.

3. Tindakan

Apa yang seharusnya dilakukan oleh pemerintah dalam mengimplementasikan Perda No 03 Tahun 2010 adalah dengan mengetahui apa yang menjadi hak, hewajiban, tugas dan fungsi yang dimiliki. Sehingga mereka mengetahui apa yang harus dilakukan untuk melakukan penanggulang perdagangan orang. Peningkatan kualitas pejabat publik; adanya evaluasi, adanya punishment (hukuman); 
perbaikan dalam perumusan program; dan pemilihan media sosial, menjadi alat bantu untuk melengkapi kekurangan pelaksanaan Perda saat ini.

\section{Saran}

Angka perdagangan manusia di Kabupaten Cianjur terus meningkat setiap tahunnya, walaupun telah memiliki Perda No 03 Tahun 2010, Peraturan Bupati tentang Petunjuk Pelaksanaan Perda, P2TP2A, dan Gugus Tugas sebagai lembaga koordinasi yang memiliki program kerja. Kebijakan-kebijakan tersebut belum mampu untuk meminimalisir permasalahan ini, sehingga Cianjur masih menempati peringkat ke-tiga di Jawa Barat sebagai Kabupaten dengan angka korban trafficking yang tinggi. Walaupun menurut Riant Nugroho 60 persen keberhasilan kebijakan dilihat dari implementasinya, namun dalam menyelesaikan permasalahan kasus trafficking yang terjadi di Kabupaten Cianjur diperlukan sebuah penguatan kelembagaan P2TP2A.

Penguatan kelembagaan ini dilakukan melalui revisi Peraturan Daerah No 03 tahun 2010 tentang Penanggulangan Perdagangan Orang. Sehingga memperkuat dan memperjelas peran dan fungsi P2TP2A. Hal ini dianggap perlu karena P2TP2A merupakan pusat pelayanan yang memegang peran yang sentral dalam penanggulangan perdagangan manusia di Kabupaten Cianjur, walaupun P2TP2A hanya merupakan salah satu anggota Gugus
Tugas. namun dengan adanya P2TP2A, OPD-OPD terkait merasa trafficking bukanlah tanggungjawabnya. Sehingga tidak adanya prioritas dari instansi pemerintah, dengan minimnya program dan tidak adanya pengalokasian anggaran khusus tindak pidana perdagangan orang.

\section{DAFTAR PUSTAKA}

Affandi, Muchtar. 1982. Ilmu-Ilmu kenegaraan. Bandung: Lembaga Penerbitan Fakultas Sosial Politik Universitas Padjadjaran

Ali, Faried, dkk. 2012. Studi Analisa Kebijakan. Bandung: PT Refika Aditama

Arikunto, Suharsimi. 2010. Prosedur Penelitian Suatu Pendekatan Praktik. Jakarta: Rineka Cipta

Budiardjo, Miriam. 2000. DasarDasar Ilmu Politik. Jakarta: PT. Gramedia Pustaka Utama

Bungin, Burhan. 2007. Penelitian Kualitatif. Jakarta: Kencana Prenada Media Group

Charles, O Jones. 1991. Pengantar Kebijakan Publik. Jakarta: PT. Rajawali

Dunn, William N. 2003. Analisis Kebijakan Publik. Yogyakarta : Gajah Mada University Press

Lapian, Gandhi, Hetty A. Geru. 2006. Rafficking Perempuan dan Anak. Jakarta : Yayasan Obor Indonesia

Luankili, Bernadus. 2007. Analisis Kebijakan Publik dalam Proses Pengambilan Keputusan. 
Jakarta: Institut Pemerintahan Dalam Negeri

Moleong, Lexy J. 1996. Metodologi

Penelitian Kualitatif. Bandung

: PT. Remaja Rosdakarya

Nugroho, Riant. 2009. Public Policy. Jakarta: PT Elex Media

Komputindo

$$
\begin{aligned}
& \text { 2002. Public Policy. } \\
& \text { Jakarta: PT. Elex } \\
& \text { Media Komputindo. }
\end{aligned}
$$

Nurcholis, Hanif. 2007. Teori dan

Praktik Pemerintahan dan

Otonomi Daerah. Jakarta: PT

Gramedia

Widiasarana

Indonesia

Parson, Waine. 2006. Publik Policy.

Jakarta: Kencana Prenada

Goup

Rasyid, Muhammad Ryaas. 2007.

Makna Pemerintahan. Jakarta:

PT Mutiara Sumber Widya

Riawanti, Selly.2003. Metode

Kualitatif dalam Ilmu-Ilmu

Sosial. (modul) Kerjasama

Inspektorat

Jendral

Departemen Pendidikan

Nasional dan Lembaga

Penelitian Unpad

Sagala, R sagala, Ellin Rozana. 2007.

Memberantas

Trafficking

Perempuan dan Anak.

Bandung : Pojok 85

Sarundajang. 2001. Arus Balik

Kekuasaan Pusat ke Daerah.

Jakarta : Pustaka Sinar

Harapan

Sugiono. 2007. Metode Penelitian

Kualitatif. Bandung : Alfabeta

- .. 2010. Metode

Penelitian Kuantitatif, Kualitatif dan

$R \& D$. Bandung: Alfabeta
Suharto, Edi. 2008. Analisis Kebijakan Publik. Bangung: Alfabeta

2008. Kebijakan

Sosial Sebagai Kebijakan

Publik. Bandung: Alfabeta

Surianingrat, Bayu. 1992. Mengenal Ilmu Pemerintahan. Jakarta: PT RINEKA CIPTA

Suyanto, Bagong. 2010. Metode Penelitian Sosial. Jakarta: Kencana Prenada Media Group Syafiie, Inu kencana. 2007. Ilmu Pemerintahan. Bandung: Mandar Maju

Syafrizal. 2009. Teknik Praktis Penyusunan Rencana Pembangunan Daerah. Baduose Media

Syaukani, dkk. 2003. Otonomi Daerah Dalam Negara Kesatuan. Yogyakarta : Pustaka Pelajar

Widodo, Joko. 2006. Analisis Kebijakan Publik. Malang: Bayumadia Publishing Winarno, Budi. 2012. Kebijakan Publik. Jakarta : CAPS , 2009. Pokok-Pokok

Analisis Kebijakan Publik. Bandung: Mandar Maju.

Jurnal Perempuan. 2007. Mengapa Mereka di Perdagangkan?. Jakarta : Yayasan Jurnal Perempuan

Jurnal Perempuan. 2010. trafficking dan kebijakan. Jakarta : Yayasan Jurnal Perempuan

Penelitian program desentralisasi, analaisis kebijakan pemerintah tentang pencegahan dan penenganan korban perdagangan orang 
(trafficking) di Kabupaten Garut tahun 2013.LPPM Unpad, 2013

Undang-Undang No 23 tahun 2002 Pasal 1 Ayat 2

Peraturan Daerah Kabupaten Cianjur No 03 Tahun 2010 Pasal 1 Ayat 7

Keputusan Bupati Nomor Nomor 463/Kep.113-Ks/2009 tentang Pembentukan Pusat Pelayanan Terpadu Pemberdayaan Perempuan dan Anak

Keputusan Bupati Nomor Nomor 182/Kep.124-Ks/2009 tentang Pembentukan Gugus Tugas pencegahan dan Penanganan Tindak Pidana Perdagangan Orang

Peraturan Bupati Nomor 49 Tahun 2011 tentang Petunjuk Pelaksanaan Peraturan Daerah No 03 Tahun 2010 Tentang Penanggulangan Perdagangan Orang

Kesepakatan Bersama Nomor 146/988.b/BKBPP;

2254.1/KESGA-GM/X/2011;

445/17/RSUD/2011; 306/RSC/X/201;

23.B/Sekrt/P2TP2A/Kab.cjr/20

11 tentang Penatalaksanaan Pelayanan Terpadu Korban Kekerasan Terhadap Perempuan dan Anak di Rumah Sakit di Kabupaten Cianjur.

Arrahman.com. $60 \%$ Korban Human Trafficking Berasal dari Jabar.11 Juni 2010.25 Januari 2014. http://www.arrahmah.com/read 12010/06/11/8094. Diakses pada tanggal 25 januari 2014
Beni Bastiandi, Pemkab Advokasi Buruh Korban Penyekapan. http://www.inilahkoran.com/re ad/detail/2033892/ . Diakses pada tanggal 3 Februari 2014 Cianjur Lumbung Kasus Perdagangan

Manusia.http://m.inilah.com/re ad/detail/1914649/. Diakses pada tanggal 2 januari 2014

Esih Sukaesih Karo. Perkosaan Terhadap Anak di Kabupaten Cianjur Terus Terjadi .metrotvnews.com/metronews/r ead/2013/10/09.Editor Patna Budi Utami. Diakses pada tanggal 5 januari 2014

Kanal 3.Kasus Perdagangan Manusia Indonesia Tertinggi di Dunia. http://kanaltiga.blogspot.com/. Diakses pada tanggal 24 januari 2014

Liya Yulia dalam Riva Fauzia. Kabupaten Cianjur Rawan Kasus Trafficking.23 Agustus 2007.26 Januari 2014.Melalui http://rivafauziah.blogdetik.co m. Diakses Pada tanggal 26 Januari 2014

Qory Delasera. Tenaga Kerja Indonesia Bukan Komoditas. http://politik.kompasiana.com.

Diakses pada tanggal 25 januari 2014

Seputar Indonesia.com. Jabar Tertinggi Kasus Trafficking.http://www.gugus tugas trafficking.org/index. Diakses pada tanggal 25 Januari 2014 
Susanne Febrianti dalam Beni, Bastiandy.Perda Trafficking Cianjur tak Efektif. Inilah.com.http://m.inilah.com/ read/detail/ 1914691/.Diakses pada tanggal 14 januari 2014 